\title{
A Bizarre Accident: A Boy with a Needle in the Posterior Urethra
}

\author{
Bir Garip Kaza: Posterior Üretrasında İğne Olan Bir Çocuk
}

\author{
ID Yonca Senem Akdeniz ${ }^{\mathbf{1}}$ (iD) Musa Balta $^{2}$, (D) Afsin Ipekci ${ }^{\mathbf{1}}$, IDrahim Ikizceli ${ }^{\mathbf{1}}$ \\ 1- Istanbul University-Cerrahpasa, Cerrahpasa Medical Faculty, Department of Emergency Medicine, Istanbul, Turkey. 2- Beylikduzu State \\ Hospital, Istanbul, Turkey
}

\begin{abstract}
Objectives: Self-insertion of penile foreign bodies is a common phenomenon worldwide. In the literature, there are numerous reported cases of self-inflicted foreign objects in the urethra but in Turkey, the reported cases are relatively few and these are usually adult cases.

Case: An 11 years-old male presented to the emergency department with inadvertently slipping a needle in his urethra after itching the urethral orifice with the needle. A plain x-ray of the pelvis showed a needle approximately about the level of the posterior urethra. By cystoscopy, the needle is completely removed from the bulbar urethra without any complication.

Conclusion: Cases of self-inserted urethral bodies are not rare. Patients often present with voiding symptoms such as dysuria, pyuria, increased urinary frequency, hematuria, urinary retention, and penile or perineal swelling. Pelvic x-ray is usually sufficient for diagnosis; ultrasonography and computerized tomography are the next choices. Endoscopic retrieval is the initial management and, in most cases, it is successful; open surgery is rarely required.

ÖZET

Amaç: Penis içine yabancı cisim yerleştirilmesi tüm dünyada görülen bir fenomendir. Literatürde sayılı vaka bildirimleri vardır ancak Türkiye' de bildirilen vakalar göreceli olarak çok azdır ve çoğunlukla yetişkindirler.

Olgu: Acil servise 11 yaşında erkek hasta üretra dış ucunu kaşırken iğnenin yanlışlıkla kayıp üretra içine girmesi şikayeti ile başvurdu. Düz pelvis grafisinde posterior üretra seviyesinde iğne görüldü. Sistoskopi ile iğne bulbar üretradan çıkarıldı.

Sonuç: Kendi üretrasına yabancı cisim yerleştirme vakaları nadir değildir. Hastalar çoğunlukla dizüri, piyüri, sık idrara çıkma,hematüri, idrar retansiyonu, penis veya perineal bölgede şişme şikayeti ile başvururlar. Tanı için düz pelvis grafisi çoğunlukla yeterlidir, ultrasonografi ve bilgisayarl tomografi diğer seçeneklerdir. Tedavide endoskopik olarak çıkarma ilk seçenektir ve çoğu vakada başarılı sonuç alınır ancak nadiren açık cerrahi işlem gerekebilir.
\end{abstract}

Keywords:

Urethra,

Foreign body,

Emergency department.

Anahtar Kelimeler:

Üretra,

Yabancl cisim,

Acil servis

\section{INTRODUCTION}

Self-insertion of penile foreign bodies is a common phenomenon worldwide. The aim is usually enhancing sexual performance and virility. Especially for young adolescents, the reason is just curiosity or desire for autoerotic stimulation. In the literature, there are numerous reported-cases of self-inflicted foreign objects in the urethra but in Turkey, the reported cases are relatively few and these are usually adult cases. We report a case of a urethral self-inserted needle by an 11year-old male.

\section{CASE}

An 11-year-old male accompanied by his father presented to the emergency department with inadvertently slipping a needle in his urethra after itching the urethral orifice with the needle. He did not have any complaints or symptoms. His physical examination was entirely normal. A plain X-ray of the pelvis showed a needle approximately about the level of the posterior urethra (figure 1). For the removal of the object, the patient was interned in the pediatric surgery unit. By cystoscopy, the needle is completely removed from the bulbar urethra without any complication. After the control cystoscopy which was completely normal the patient was referred to the pediatric psychiatry department for psychiatric management.

\section{DISCUSSION}

Admission with a complaint of objects in the penile urethra is unusual in the emergency department. In the literature, there are several case reports, some small case series, and very few long-time observational studies. According to a study done in the United States the incidence of emergency department visits with genitourinary foreign bodies is likely 7.6 per 100.000 persons, the admission rate of these visits is only $4.7 \%$ and, the patients were more likely males $(1,2)$.

In the reports, the age of the cases ranges from 3 to 85 , but the mean age was 28.1 in a long-term study (3-5). In another long-term study, the peak age $\mathrm{f}$ or penile object insertion was 28.3 years (range, 19-40 years) (6). 


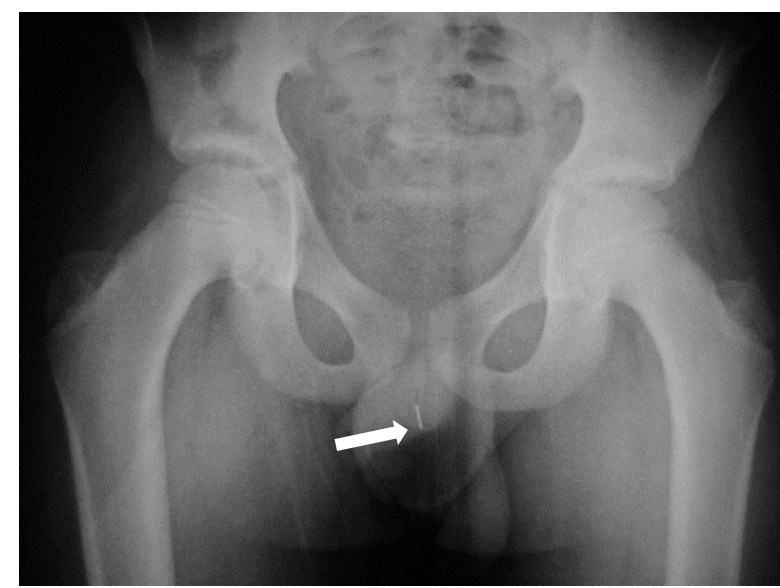

Figure 1: Pelvic X-ray of the patient shows a dense metallic object at the level of urethra.

According to a pediatric research, the peak ages for insertion of urogenital tract foreign bodies were 3-5 and 9-13 years old, patients under 6 years were usually girls and patients over 11 were usually boys (3).

The major symptoms are usually dysuria, frequency, pain, swelling, hematuria, and urinary retention but the patients may present without symptom (1-7).

Generally, pelvic X-ray is sufficient for the determination of exact location and morphology but if the object is not radiolucent, we can use computerized tomography, ultrasound, or sometimes endoscopy $(2,4)$.

Many foreign bodies were observed including pencils, ballpoint pens, rocks, AAA batteries, glass beads, straws, eye-wear rims, open safety pins, speaker wire, plastic caps, toothbrush handle, sewing needle, bullet, twigs, buckshot, nail scissor, mineral oils like paraffin, seeds, magnets (1-8).

Removal by endoscopy is the first choice for the treatment and usually is successful, but rarely a perineal urethrotomy is required $(2,4)$. Intravenous broadspectrum antibiotics are required before the procedure and must be followed by oral antibiotherapy (2).

The most common complications are mucosal tears, false passage, wide ulcers, phimosis, fistulas, and strictures usually associated with multiple bodies and repeated multiple insertions $(2,6)$. Fistulas are quite rare; there are only three reported cases of urethra cutaneous fistula due to foreign objects (9). Nevertheless, sometimes the patient can be present in the emergency room with sepsis and it may end up with penile necrosis (10). Besides, mortal complications as Fournier's gangrene have been reported (11).

The diagnosis might be very difficult with mentally ill patients if there are no obvious signs or symptoms for foreign urethral objects. There is a 16 years old schizophrenia case with foreign body insertion diagnosed with the help of a parent's report (12). It has been reported that there is a significant association between penile and urethral foreign body insertion and having a mental health disorder (\%35.6) (1).

Conclusion: Cases of self-inserted urethral bodies are not rare. Various objects have been reported. This behavior is often associated with psychiatric disorders, senility, intoxications, or autoerotic stimulation. Patients often present with voiding symptoms such as dysuria, pyuria, increased urinary frequency, hematuria, urinary retention, and penile or perineal swelling. Pelvic x-ray is usually sufficient for diagnosis; ultrasonography and computerized tomography are the next choices. Endoscopic retrieval is the initial management and, in most cases, it is successful; open surgery is rarely required. For avoiding infective complications antibiotherapy is necessary. Psychiatric evaluation of these patients is indispensable.

\section{Conflicts of Interest}

The authors have no conflicts of interest to declare.

\section{REFERENCES}

1. Rodríguez D, Thirumavalavan N, Pan S, Apoj M, Butaney M, Gross MS, Munarriz R. Epidemiology of genitourinary foreign bodies in the united states emergency room setting and its association with mental health disorders. Int J Impot Res. 2020; 32:426-433.

2. Rahman NU, Elliott SP and Mcaninch JW. Self-inflicted male urethral foreign body insertion: endoscopic management and complications. BJU International. 2004;94:1052-1053.

3. He Y, Zhang W, Sun N, Feng G, Ni X, Song H. Experience of pediatric urogenital tract inserted objects: 10-year single-center study. J Pediatr Urol. 2019;15(5):554.e1-554.e8.

4. Mahadevappa N, Kochhar G, Vilvapathy KS, Dharwadkar S, Kumar S. Self-inflicted foreign bodies in lower genitourinary tract in males: Our experience and review of literature. Urol Ann 2016;8:338-42.

5. Gunasekaran K, MurthiIn S. Unusual metallic penile foreign body. BMJ Case Rep 2017;1-2

6. Pehlivanov G, Kavaklieva S, Kazandjieva J, Kapnilov D, Tsankov N. JEADV. Foreign-body granuloma of the penis in sexually active individuals (penile paraffinoma). 2008;22:845-851.

7. Zaghbib S, Ouanes Y, Chaker K, Ben Chehida MA, Daly KM, Nouira Y. Urethral self-inserted sewing needle in a 14-year-old boy for autoerotic stimulation. Urology Case Reports. 2019;25:1-3

8. Cam B, Tuncer H, Uzun O, Uysal E. Nail scissor as a rare foreign body in the urethra: Case report. Cureus 11(1): e3851.

9. Kinjo T1, Oka T1, Imanaka T1, Yamanaka Y1, Nomura H1, Yoshioka I1, Takada S. Urethrocutaneous fistula caused by a vesical foreign body in an adolescent boy: a case report. Acta Urol Jap. 2019;65(8):341-345.

10. Hwang EC, Kim JS, Jung SI, Im CM, Yun BH, Kwon DD, et al. Delayed Diagnosis of an Intraurethral Foreign Body Causing Urosepsis and Penile Necrosis. Jun Eul Hwang. Korean J Urol. 2010;51:149-151. 
Phnx Med J. November, 2020. Volume 2 No 3

11. Elawdy M, El-Halwagy S, Mousa EE, and Maliakal J. Self-insertion of an odd ureth ral foreign body that led to Fournier's gangrene. Urol Ann. 2019;11(3):320-323.

12. Ahsaini M, Bounoual M, Mellas S, El Ammari J, Tazi MP, El Fassi MJ, Farih MH. Corps étranger intra urétral inhabituel chez un adolescent schizophrène: à propos d’un cas. Pan African Medical Journal. 2018;31:217. 